\title{
Enhancing the spontaneous imbibition process using biosurfactants produced from bacteria isolated from Al-Rafidiya oil field for improved oil recovery
}

\author{
Asaad Faraj Hamzah ${ }^{1}$. Mohammed Idrees Al-Mossawy ${ }^{2}$. Wijdan Hussein Al-Tamimi ${ }^{3}$. Fahad M. Al-Najm ${ }^{4}$. \\ Zainab Mohsen Hameed ${ }^{5}$
}

Received: 26 November 2019 / Accepted: 25 March 2020 / Published online: 15 April 2020

(c) The Author(s) 2020

\begin{abstract}
Among 64 bacterial strains isolated in this study, the best two of biosurfactant-producing bacteria were selected and identified based on the phenotypic properties and molecular approach based on 16S rRNA having 100\% similarity to the gram-negative Enterobacter aerogenes B19 strain bacteria and rode gram-positive strain Bacillus cereus ISU-02 in the Nucleotide database of the National Center for Biotechnology Information. The study showed that two selected isolates gave the highest positive results that were used to investigate the biosurfactant production including: interfacial reduction, foaming activity, hemolytic activity, CTAB agar plate, drop collapse assay, oil displacement test and emulsification index E24\%. Both Bacillus cereus ISU-02 strain and Enterobacter aerogenes B19 strain have reduced the interfacial tension to 27.61 and 28.93, respectively. Biosurfactants produced from both isolates were tested for oil recovery using spontaneous imbibition process. Bacillus cereus ISU-02 strain gave the highest oil recovery of $66.9 \%$ for rock permeability of $843 \mathrm{mD}$, followed by Enterobacter aerogenes B19 strain with oil recovery of $34 \%$ for rock permeability $197 \mathrm{mD}$, while the lowest rate of oil recovery was $12.1 \%$ for FW with permeability of $770 \mathrm{mD}$. An additional oil rate reached to $7.9 \%$ has been recovered from the residual oil when the core plug that was treated with formation water alone was retreated with the cell free biosurfactant supernatant. Use of the new biosurfactants has improved oil recovery better than use of formation water alone or formation water with the commercial surfactant SDS.
\end{abstract}

Keywords Oil field bacteria $\cdot$ MEOR $\cdot$ Spontaneous imbibition

Asaad Faraj Hamzah

asaadfaraj@yahoo.com

1 Technical Institute of Basrah, Southern Technical University, Basrah, Iraq

2 Collage of Petroleum Engineering Al-Ayen University, Nasiriyah, Iraq

3 Department of Biology, Science Collage, University of Basrah, Basrah, Iraq

4 Department of Geology, Science Collage, University of Basrah, Basrah, Iraq

5 Research and Quality Control Department, Basrah Oil Company, Basrah, Iraq

\section{Introduction}

In most of oil fields, only a small portion of crude oil can be recovered by traditional recovery methods. After the primary and secondary recovery, up to $66 \%$ of oil stays caught in the reservoir rocks (Nnaemeka et al. 2018). Water flooding is the most important technique in the secondary recovery stage. This technique includes injecting water in hydrocarbon-bearing zones through a series of injection wells to sweep the trapped oil toward producing wells (Nikzad Amoli 2011). Enhanced oil recovery (EOR) techniques are used to recover the residual oil from reservoir rocks after the primary or secondary stages. One of EOR methods is injection of surfactants with water to improve the sweep efficiency of water flooding technique (Sheng 2010). Many commercial cationic surfactants were able to recover $50-90 \%$ of oil (Standnes and Austad 2003 and Strand et al. 2003). Surfactants play an active role in enhanced spontaneous imbibition in oil 
reservoirs. The surfactant decreases the oil-water interfacial tension and oil-rock surface tension, as well as it may alter the rock wettability to be water-wet through its interaction with rock surface compounds (Austad et al. 2018; Xiao et al. 2016; Pal et al. 2018). But these surfactants are usually harmful to the environment and costly (Abouseoud et al. 2008). Under certain circumstances, bacteria are able to grow under aerobic and anaerobic conditions and saline within oil reservoirs and can be induced to produce biosurfactants which adsorbed on the rock surface and change the reservoir to nearly water-wet (Golabi et al. 2009). The biosurfactants that produced by microorganisms diminish the capillary forces that impede the movement of oil through the pores of rock by reducing oil-rock surface tension. Besides aid in the breakdown of the oil film in the rock by emulsification by dissolving oil with water by emulsification (Al-Bahry et al. 2013). The process by which the use of microorganisms in oil reservoirs to enhanced recovery of the residual oil called microbial enhanced oil recovery (MEOR) (Rashdi et al. 2012). The prime objective of the present study was to isolate indigenous bacteria from produced water. The isolated bacteria were tested to produce biosurfactants which have been used to enhance oil recovery by a spontaneous imbibition process.

\section{Materials and method}

\section{Sample collection}

Bacterial strains used in this study were isolated from produced water of Al-Rafidiya oil field (Zubair 2 oil field), Basra, in south of Iraq $30.16^{\circ} \mathrm{N} 47.42^{\circ} \mathrm{E}$ as. All formationwater samples were collected from the stock tank after the separator. Data of physical and chemical properties of the water samples were collected from the daily production reports. All samples were transported from the field to our laboratory in an ice bag under temperature of $4{ }^{\circ} \mathrm{C}$.

\section{Stimulation of indigenous microorganism}

To stimulate indigenous microorganisms, $5 \mathrm{ml}$ of produced water was added to Erlenmeyer flask size $250 \mathrm{ml}$ containing $95 \mathrm{ml}$ of mineral estimated media (MSM) composed of $2 \%$ of crude oil as a carbon source, $1 \mathrm{~g} / \mathrm{L} \mathrm{KH}_{2} \mathrm{PO}_{4}, 6 \mathrm{~g} / \mathrm{L}$ $\mathrm{NaNO}_{3}, 1 \mathrm{~g} / \mathrm{L} \mathrm{K}_{2} \mathrm{HPO}_{4}, 0.02 \mathrm{~g} / \mathrm{L} \mathrm{FeSO}_{4}, 0.5 \mathrm{~g} / \mathrm{L} \mathrm{MgSO}_{4}$ and $0.02 \mathrm{~g} / \mathrm{L} \mathrm{Na}_{2} \mathrm{MoO}_{4}$ at a pH of 7.0-7.2 at a pH of 7.0-7.2 (Zhao et al. 2017). Then the mixture was shaken at 180 r.p.m and $35{ }^{\circ} \mathrm{C}$ for $48 \mathrm{~h}$ using shaker incubator. Volume of $1 \mathrm{ml}$ of the suspension was diluted serially and plated in triplicate on nutrient agar and MacCkonkey agar. The plates were incubated at $35^{\circ} \mathrm{C}$, and streaks were isolated again on nutrient agar to obtain pure isolates. These isolates were kept on nutrient agar slants.

\section{Identification of bacterial isolates}

\section{Morphological characterization}

Pure isolated colonies that have grown on the nutrient agar plates were examined and recorded as colony morphological characteristics. Bacterial shape and gram stain recorded for all isolates.

\section{Molecular identification}

Genomic DNA was extracted from culture by using a commercial kit protocol (Promega Genomic DNA Purification Kit, USA). 16S rRNA genes were amplified using polymerase chain reaction (PCR) was carried out the universal specific primer (27FAGAGTTTGATCMTGGCTCAG) and (1492RTACGGYTACCTTGTTACGACTT) PCR mixture contained $5 \mu 1$ of DNA, $2 \mu 1$ of each primers solution, master mix $25 \mu \mathrm{l}$ and $16 \mu \mathrm{l}$ nuclease-free water. Amplification was carried out with thermal cycle machine after initial denaturation for $3 \mathrm{~min}$ at $95^{\circ} \mathrm{C}$, and 30 cycles were performed, with each cycle consisting of $20 \mathrm{~s}$ at $95^{\circ} \mathrm{C}, 20 \mathrm{~s}$ at $55^{\circ} \mathrm{C}$ and $30 \mathrm{~min}$ at $72{ }^{\circ} \mathrm{C}$. Cycling was completed by a final elongation step at $72{ }^{\circ} \mathrm{C}$ for $5 \mathrm{~min}$ (Gittel et al. 2009). Approximately 1500-bp 16S rDNA of each isolates was purified and sequenced at Yang ling tianrun aoke biotechnology company laboratories/China. The bacterial 16S rDNA obtained sequencing was then aligned with known 16S rDNA sequences Gen bank using the Basic Local Alignment Search Tool (BLAST) at the National Center for Biotechnology Information (NCBI).

\section{Screening of biosurfactant-producing bacteria}

The selected strains were inoculated for $48 \mathrm{~h}$ in mineral salt media (MNS) for screening of biosurfactant production (Tabatabaee et al. 2005). The medium has following composition: glucose; $20 \mathrm{~g}$ as a carbon source, $\mathrm{K}_{2} \mathrm{HPO}_{4}$; $5 \mathrm{~g}, \mathrm{KH}_{2} \mathrm{PO}_{4} ; 20 \mathrm{~g}, \mathrm{NaCl} ; 0.1 \mathrm{~g}, \mathrm{MnSO}_{4} .7 \mathrm{H}_{2} \mathrm{O} ; 0.22 \mathrm{~g}$, $\left(\mathrm{NH}_{4}\right)_{2} \mathrm{SO}_{4} ; 30 \mathrm{~g}, \mathrm{FeSO}_{4} .7 \mathrm{H}_{2} \mathrm{O} ; 0.01 \mathrm{~g}, \mathrm{CaCl}_{2} .2 \mathrm{H}_{2} \mathrm{O} ; 0.02 \mathrm{~g}$, $\mathrm{MgSO}_{4} .7 \mathrm{H}_{2} \mathrm{O} ; 0.2 \mathrm{~g}$, and distilled water up to $1000 \mathrm{ml}$ adding $1 \mathrm{~mL}$ of trace element stock solution which composed of $(\mathrm{g} / \mathrm{L}): \mathrm{FeCl}_{3} \cdot 6 \mathrm{H}_{2} \mathrm{O} \mathrm{ZnSO} \mathrm{Zn}_{4} \cdot 7 \mathrm{H}_{2} \mathrm{O} 0.75, \mathrm{CoCl}_{2} \cdot 6 \mathrm{H}_{2} \mathrm{O}$ $0.08, \mathrm{CuSO}_{4} .5 \mathrm{H}_{2} \mathrm{O} 0.075, \mathrm{MnSO}_{4} \cdot \mathrm{H}_{2} \mathrm{O} 0.75, \mathrm{H}_{3} \mathrm{BO}_{3} 0.15$, $\mathrm{Na}_{2} \mathrm{MoO}_{4} \cdot 2 \mathrm{H}_{2} \mathrm{O} 0.05$. The $\mathrm{pH}$ of medium was maintained at 7-7.2. Erlenmeyer flask was inoculated with $2 \%$ inoculum and incubated at $37{ }^{\circ} \mathrm{C}$ in shaker at $180 \mathrm{rpm}$ for $72 \mathrm{~h}$. The culture was centrifuged at $12,000 \mathrm{rpm}$ for $30 \mathrm{~min}$, and 
the cell-free supernatant (CFS) was used for detection of biosurfactant production.

\section{Investigation of biosurfactant production}

\section{Surface tension}

Surface tension was determined using Tensiometer (sigma $700 /$ Sweden) by ring method on $125 \mathrm{ml}$ of each bacterial supernatant at room temperature. The results were compared to sterile medium as negative control (Rosli Wan Sulaiman and Soo Lee 2012).

\section{Foaming activity}

Foaming activity is detected as length of froth stability and foam form by shaking vigorously the supernatant $10 \mathrm{ml}$ for $2 \mathrm{~min}$, the foaming formation was calculated according to the following equation (El-Sheshtawy 2012).

Foming $=($ Height of foam $/$ Total height $) \times 100$

\section{Hemolytic activity}

All of the isolated strains were tested for hemolytic activity using human blood agar plate incubated for $24 \mathrm{~h}$ at $37{ }^{\circ} \mathrm{C}$ to as-say hemolytic activity. The plates were then observed for the presence of clear zone around the colonies indicating biosurfactant production (Carrillo et al. 1996; Bicca et al. 1999).

\section{CTAB agar plate method}

Detection of crude biosurfactant CTAB agar plate strategy is a semiquantitative assay for the identification of anionic surfactants (Thavasi et al. 2011). Blue agar plates contain cetyltrimethylammonium bromide (CTAB $0.2 \mathrm{mg}$ / $\mathrm{ml}$ ), methylene blue (MB $0.5 \mathrm{mg} / 100 \mathrm{ml}$, basic dye) and glucose $(2 \% \mathrm{v} / \mathrm{v})$. Pits were made in CTAB agar medium using a sterile cork borer and filled with $50 \mu \mathrm{L}$ of the culture supernatant. Anionic biosurfactants were observed by the formation of dark blue halos around the pit (Cooper and Goldenberg 1987).

Detection of isolate colony Cetyltrimethylammonium bromide (CTAB)-methylene blue agar was prepared by adding $0.2 \mathrm{~g}$ CTAB, $0.005 \mathrm{~g}$ methylene blue and $15 \mathrm{~g}$ agar to $1 \mathrm{~L}$ mineral salts medium. Agar plates contained $20 \mathrm{ml}$ medium inoculate with single colony incubated at $30{ }^{\circ} \mathrm{C}$ for $24 \mathrm{~h}$. Biosurfactants production was observed by the formation of dark blue halos around the colony (Siegmund and Wagner 1991).

\section{Drop collapse assay}

Biosurfactant decreases the surface tension between water and hydrophobic surfaces such as parafilm, the ability to collapse a droplet of water was tested by pipetted $25 \mu \mathrm{l}$ of extracted biosurfactant as a droplet onto parafilm, and over seconds or minutes the flattening and the spreading of the droplet on the parafilm surface were followed. No influence on the shape of the droplets dye (methylene blue) was added to the water spot for photographic purposes. The droplet was allowed to dry, and the diameter of the dried droplet was recorded by ruler (Kuiper et al. 2004; Tugrul and Cansunar 2005).

\section{Oil displacement methods}

Oil spreading test was performed and described by Morikawa et al. (2000). In this method, $20 \mathrm{ml}$ of distilled water was added to a Petri dish ( $15 \mathrm{~cm}$ of diameter) followed by addition of $20 \mu \mathrm{l}$ of crude oil dropped on the water surface to form a film covering the entire water surface area. Ten microliters of cell free broth culture was then added to the oil surface. The oil will be displaced with an oil-free clearing zone, and diameter of this clearing zone indicates the presence of biosurfactant in the cell-free culture broth. The net area diameters and the oil displacement areas involved were measured to compare the efficacy of the biosurfactant.

\section{Emulsification index test E24}

The emulsification index (E24) was measured using the method described by Płaza et al. (2006). A mixture of $2 \mathrm{ml}$ of each cell-free supernatant of all selected strains was taken in separate test tubes with $2 \mathrm{ml}$ of (crude oil, olive oil, engine oil, fraying oil). The mixtures were vortexed for $2 \mathrm{~min}$ and left at room temperature for $24 \mathrm{~h}$. The percentage of E24 index was calculated by the given equation: (Barakat et al. 2017; Bento et al. 2005).

Emulsification Index $(E 24)=\frac{\text { Height of Emulsion formed }}{\text { Total height of Solution }}$

\section{Extraction of biosurfactant}

Bacterial cells were removed from surfactant-containing medium by centrifugation at $9000 \mathrm{rpm}, 20 \mathrm{~min}, 4{ }^{\circ} \mathrm{C}$. The supernatant was subjected to acid precipitation by adding

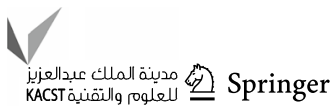


Table 1 General petrophysical properties of the core plugs

\begin{tabular}{lllll}
\hline Sample number & Depth $(\mathrm{m})$ & Gas permeability $(\mathrm{mD})$ & Porosity $(\%)$ & $\begin{array}{l}\text { Core } \\
\text { volume } \\
\mathrm{cm}^{3}\end{array}$ \\
\hline 221 & 3284.25 & NMP & 29.0 & 26 \\
222 & 3284.58 & 843 & 24.8 & 18 \\
224 & 3285.15 & 770 & 18.6 & 34 \\
225 & 3285.48 & 516 & 21.2 & 22 \\
227 & 3285.90 & 580 & 22.9 & 20 \\
230 & 3286.64 & 228 & 18.7 & 24 \\
233 & 3287.48 & 179 & 16.0 & 25 \\
235 & $3,287,096$ & 210 & 18.0 & 20 \\
\hline
\end{tabular}

Table 2 Properties of crude oil

\begin{tabular}{lllll}
\hline $\begin{array}{l}\text { Density } \\
\left(\mathrm{g} / \mathrm{cm}^{3}\right)\end{array}$ & $\begin{array}{l}\text { Viscosity } \\
(\mathrm{cp})\end{array}$ & API gravity & $\begin{array}{l}\text { Salt content } \\
(\mathrm{ppm})\end{array}$ & $\begin{array}{l}\text { Water content } \\
(\%)\end{array}$ \\
\hline 0.8516 & 5.8 & 29 & 16 & 6.5 \\
\hline
\end{tabular}

Table 3 Properties of production water

\begin{tabular}{lllll}
\hline $\begin{array}{l}\text { Density }(\mathrm{g} / \\
\left.\mathrm{cm}^{3}\right)\end{array}$ & $\begin{array}{l}\text { Surface ten- } \\
\text { sion }\end{array}$ & PH & Salinity (ppm) & $\begin{array}{l}\text { Temperature } \\
\left({ }^{\circ} \mathrm{C}\right)\end{array}$ \\
\hline 0.854 & 55.8 & 7.2 & 22 & 35 \\
\hline
\end{tabular}

$6 \mathrm{~N} \mathrm{HCl}$ to achieve a final $\mathrm{pH}$ of 2.0 and allowing a precipitate to form at $4{ }^{\circ} \mathrm{C}$. The cell free supernatant was treated with equal amount of ethyl acetate (1: 1) with good stirring and left to separate the organic phase and then filtered with the aid of a rotary evaporator under vacuum. The dark yellow viscous product was collected and evaporated at $40{ }^{\circ} \mathrm{C}$ (George and Jayachandran 2008).

\section{Imbibition experiment of enhanced oil recovery}

The two produced biosurfactants of this study have been tested for enhanced oil recovery usage. Core imbibition experiments were conducted on core plugs from Zubair oil field, south of Iraq.

\section{Properties of core plugs}

Eight core plugs of sandstone rock have been used in this test. The core plugs were supplied by Basra Oil Company (BOC) from Zubair oil field. The plugs have been cleaned, and then porosity and permeability have been measured at laboratories of BOC. General petrophysical properties of the core plugs are indicated in Table 1 .

\section{Properties of crude oil and formation water}

Tables 2 and 3 show properties of crude oil and produced water of Al-Rafidiya oil field, respectively.

\section{Saturating cores with crude oil}

First, the core plugs were dried in a hot air oven at $65^{\circ} \mathrm{C}$ for $24 \mathrm{~h}$ and mass of each dray core was measured using a sensitive balance. Figure 1a shows the dry cores. Second, the cores were saturated with crude oil using vacuum pump desiccator as shown in Fig. 1b. Mass of each saturated core was measured. Figure 1c shows cores saturated with crude oil. Mass of original oil in place and oil saturation percentage were calculated as follows:

OOIP $=$ SCW - DCW

$\mathrm{SOV}=\mathrm{OIIP} / \mathrm{OD}$
Fig. 1 a Core plugs after drying. b Saturating core plugs with crude oil. c Cores after saturation

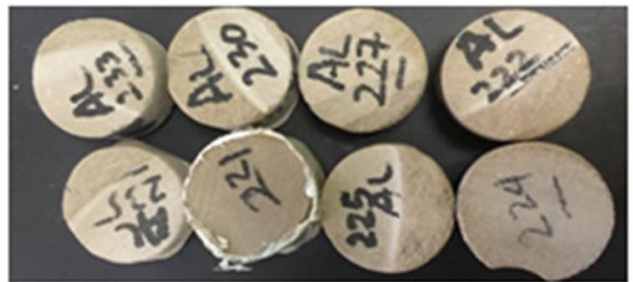

(a)

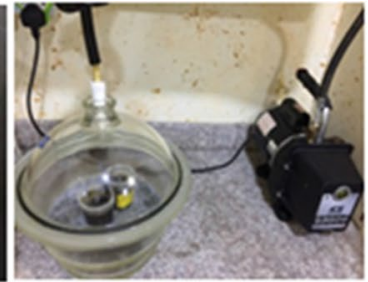

(b)

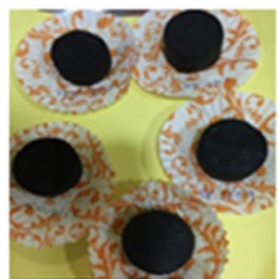

(c) 
B19 and (b cells-d colonies)
Fig. 2 (a cells-c colonies)

Enterobacter aerogenes strain

Bacillus cereus strain ISU-02

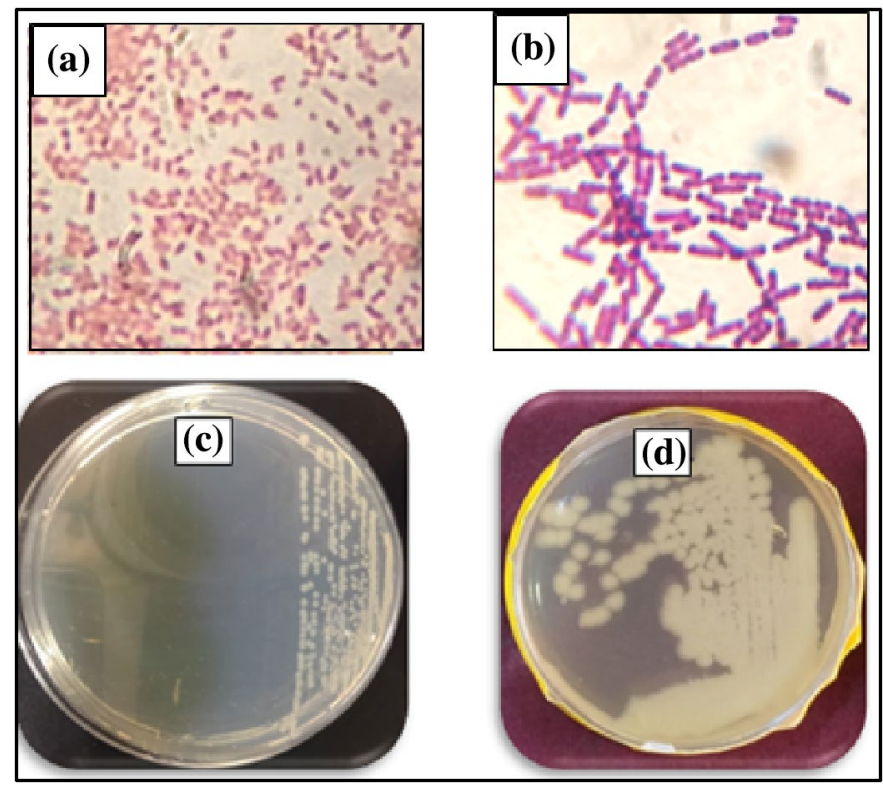

$$
\mathrm{OSP}=100 \times(\mathrm{SOV} / \mathrm{TPV})
$$

have been conducted. Table 4 shows recovery liquids and properties of cores used in these experiments. The imbibition experiments included immersing each of the core plugs saturated with oil in a cylinder filled with the recovery liquid for fourteen days at $40^{\circ} \mathrm{C}$. Then the recovered oil has been extracted from the recovery liquid using hexane (Qazi et al. 2013). The core samples 224 and 227 have been subjected to two imbibition processes sequentially. The first one included immersing each of both plugs in FW and then immersing in F.C.S.B.em to observe if any extra oil can be recovered by F.C.S.B.em after the primary recovery by FW.

The produced free cell supernatant biosurfactant (F.C.S.B.sr.), crude extracted biosurfactant (Cr.B.sr) and free cell supernatant bioemulsifier (F.C.S.B.em.) have been tested for EOR application. Effectiveness of using the new biosurfactants, bioemulsifier, formation water (FW) and the commercial surfactant sodium dodecyl sulfate (SDS) for oil recovery has been compared. Ten of imbibition experiments

Table 4 Liquids and cores used in imbibition experiments

\begin{tabular}{|c|c|c|c|c|c|c|}
\hline Run no. & Sample no. & Recovery liquid used & Porosity $\%$ & $\begin{array}{l}\text { Perme- } \\
\text { ability, } \\
\mathrm{mD}\end{array}$ & $\begin{array}{l}\text { Bulk volume } \\
\text { of plug, cc }\end{array}$ & Pore volume, $\mathrm{cc}$ \\
\hline 1 & 224 & FW & 18.6 & 770 & 34 & 6.324 \\
\hline 2 & 222 & F.C.S.B.sr & 24.8 & 843 & 18 & 4.464 \\
\hline 3 & 233 & F.C.S.B.em & 16.0 & 197 & 25 & 4 \\
\hline 4 & 230 & Cr.B.sr + FW & 18.7 & 228 & 24 & 4.488 \\
\hline 5 & 235 & $\mathrm{SDS}+\mathrm{FW}$ & 18.0 & 210 & 20 & 3.6 \\
\hline 6 & 224 Rep & F.C.S.B.Sr & 18.6 & 770 & 34 & 6.324 \\
\hline 7 & 227 & FW & 22.9 & 580 & 20 & 4.19 \\
\hline 8 & 225 & F.C.S.B.Sr & 21.2 & 516 & 22 & 4.904 \\
\hline 9 & 221 & F.C.S.B.em & 29.0 & 1914 & 26 & 6.224 \\
\hline 10 & 227 Rep & Cr. B. Sr & 22.9 & 580 & 20 & 4.19 \\
\hline
\end{tabular}


Table 5 Identification of selected isolates

\begin{tabular}{llllll}
\hline $\begin{array}{l}\text { Isolate } \\
\text { code } \\
\text { number }\end{array}$ & Gram stain & Shape & Colony properties & Bacterial strain name & $\begin{array}{l}\text { Percentage } \\
\text { identify } \\
(\%)\end{array}$ \\
\hline 36 & - & Short rode & $\begin{array}{c}\text { Yellow, round, small, entire, convex, shiny } \\
\text { whitish to creamy, large, with smooth } \\
\text { edges, flat raised elevation }\end{array}$ & $\begin{array}{c}\text { Enterobacter aerogenes strain B19 } \\
\text { Bacillus cereus strain ISU-02 }\end{array}$ \\
\hline 9 & + & Rode spore forming & 99 \\
\hline
\end{tabular}

Table 6 Screening of biosrfactant activity

\begin{tabular}{lllllll}
\hline Isolates & Surface tension & $\begin{array}{l}\text { Foaming } \\
\text { activity } \\
(\%)\end{array}$ & Hemolytic activity & $\begin{array}{l}\text { CTAB agar } \\
\text { plate method }\end{array}$ & $\begin{array}{l}\text { Drop } \\
\text { collapse } \\
\text { test }\end{array}$ & $\begin{array}{l}\text { Oil displace- } \\
\text { ment methods } \\
(\mathrm{cm})\end{array}$ \\
\hline $\begin{array}{l}\text { Entero- } \\
\text { bacter } \\
\text { aerogenes }\end{array}$ & 28.9383 & 34 & Beta-hemolytic & + & + & 7.6 \\
$\begin{array}{l}\text { strain } \\
\text { B19 }\end{array}$ & & & & & & \\
$\begin{array}{l}\text { Bacillus } \\
\text { cereus }\end{array}$ & 27.61 & 39 & Beta -hemolytic & - & + & \\
strain & & & & & & \\
ISU-2 & & & & & & \\
\hline
\end{tabular}

Fig. 3 Foaming activity of different strains comparing with control
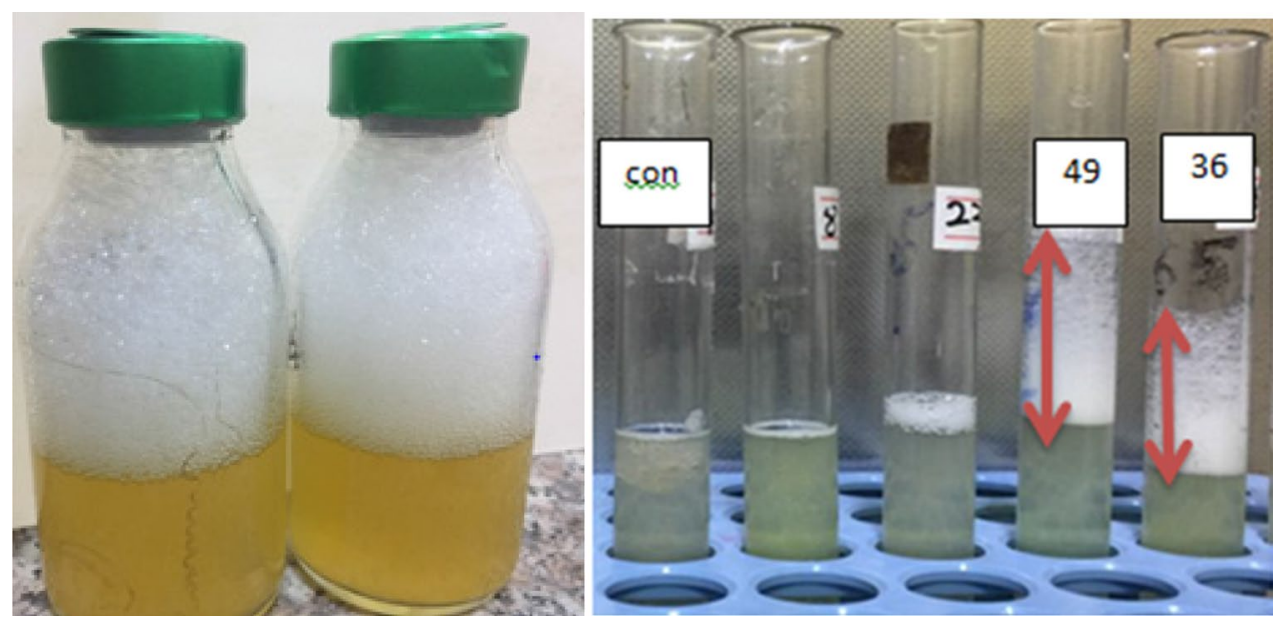

\section{Results and discussion}

\section{Isolation and identification of selected strains}

The phenotypic characteristics of cells and colonies are shown in Fig. 2. The results of molecular approach depended on 16S rRNA studies of organisms showed $100 \%$ similarities with Enterobacter aerogenes B19 strain and 99\% Bacillus cereus ISU-02 strain for, respectively, in Nucleotide database of National Center for Biotechnological Information (NCBI) (Table 5).

Zafra et al. (2014) isolated Enterobacter aerogenes with potential for polycyclic aromatic hydrocarbons (PAHs) biodegradation from heavy crude oil-contaminated soil. 

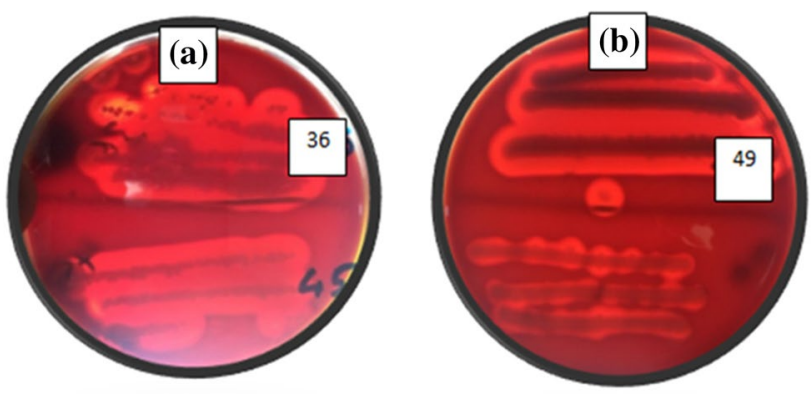

Fig. 4 Hemolytic activity of different strains: a Enterobacter aerogenes strain B19 and b Bacillus cereus strain ISU-02
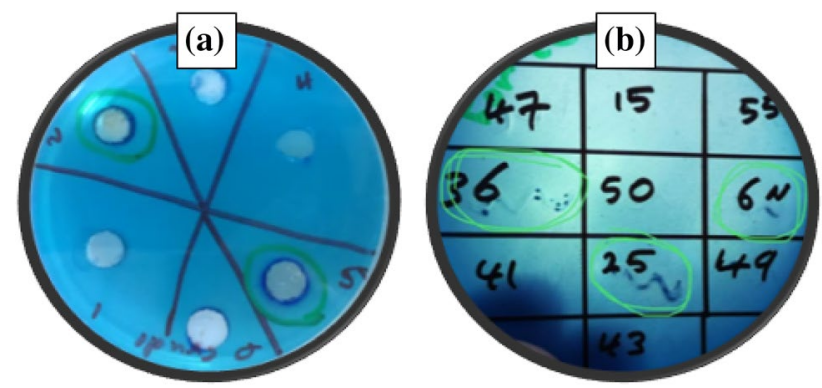

Fig. 5 CTAB agar plate method of different strains: a crude biosurfactant and $\mathbf{b}$ isolate colony

\section{Screening of biosrfactant activity}

Table 6 shows the susceptibility of selected isolates tested for biosurfactant production and their effectiveness through different screening methods.

\section{The interfacial surface tension}

The results showed ability of the two isolates Bacillus cereus strain ISU-02 and Enterobacter aerogenes B19 strain to reduce surface tension to 27.61 and 28.9383 , respectively. These results seem similar to results that obtained for surfactin which reduced surface tension of water to $25 \mathrm{mN}$ (Cooper et al. 1981), and rhamnolipids which decreased surface tension of water to $26 \mathrm{mN}$ (Syldatk et al. 1985). The interfacial
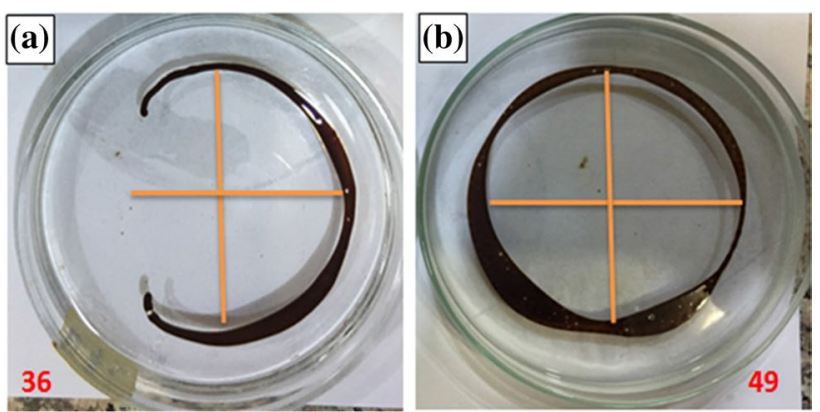

Fig. 7 Oil displacement test $\mathbf{a}-36, \mathbf{b}-49$

surface tension plays an important role in oil recovery and bioremediation of heavy crude oil (Volkering et al. 1998).

\section{Foaming activity}

Both isolates showed high foaming ability when growing on the nutrient medium stability for more than 2 days (Fig. 3). This is a good test to examine the production of biosurfactant as noted researchers Meenal and Madhura (2016).

\section{Hemolytic activity}

Both selected isolates showed excellent in hemolysis activity as shown in Fig. 4. Biosurfactants have amphiphilic in nature which can partition into the phospholipid membrane RBC (Almansoory et al. 2014).

\section{CTAP methods}

This methods use for detection of extracellular glycolipids or other anionic surfactants (Sabnis and Juvale 2016). Enterobacter aerogenes $B 19$ strain showed positive results due to formation of dark blue halos around the pit and colony (Fig. 5), while the Bacillus cereus ISU-02 strain gave a negative result.
Fig. 6 Drop collapse test a different strains comparing with control, b 49 and 36 isolates, c after drying

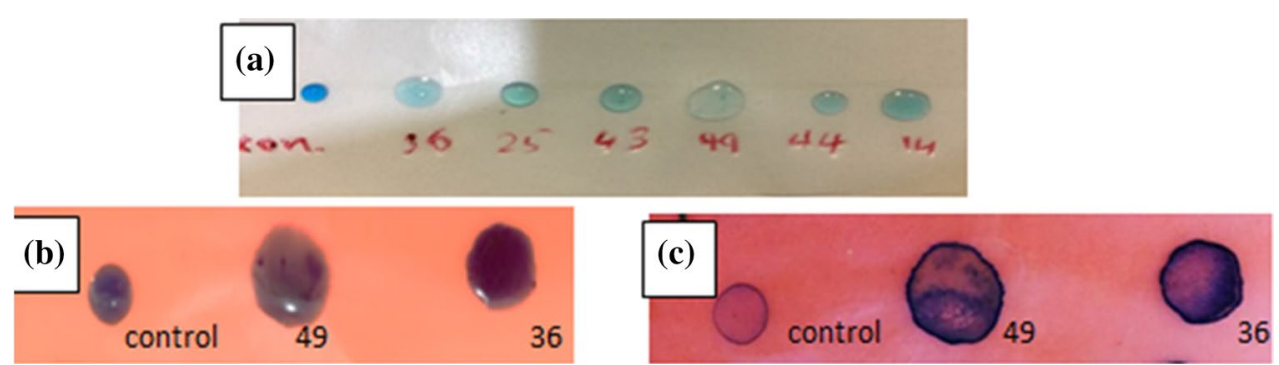


Fig. 8 Emulsification activity test with different oils left tube -49 , right -36
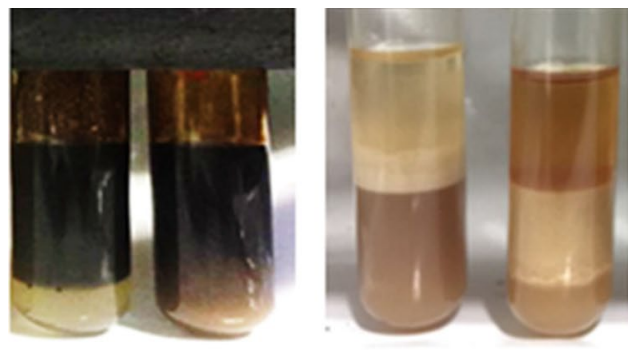

(d) Crude oil (a) Engine oil

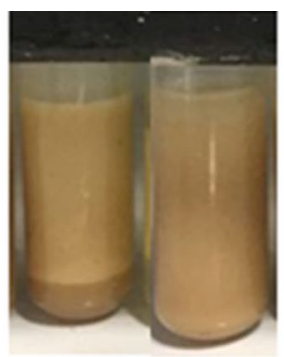

(b) Olive oil

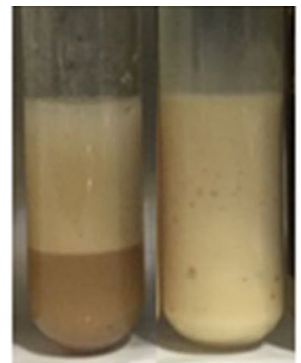

(c) Fraying oil
Table 7 Emulsification index E24\%

\begin{tabular}{lllll}
\hline Isolate & Crude oil & Engine oil & Olive oil & Fraying oil \\
\hline $\begin{array}{l}\text { Enterobacter } \\
\text { aerogenes }\end{array}$ & 90.5 & 60.5 & 94.5 & 100 \\
$\begin{array}{l}\text { strain B19 } \\
\text { Bacillus } \\
\quad \text { cereus strain }\end{array}$ & 79.5 & 30.3 & 83.4 & 70 \\
ISU-02 & & & & \\
\hline
\end{tabular}

\section{Drop-collapse test}

The two selected strains showed a positive as shown in Fig. 6. The supernatant droplets containing the biosurfactant spread or even collapse due to reduced force or tension between the liquid surfaces and the hydrophobic surface (Walter et al. 2010), while the distilled water as a negative control remains stable on the surface because the
Fig. 9 a and $\mathbf{b}$ Imbibition experiments with different liquids. c Oil flow from surface of cores. $d$ Rise of oil above the liquid surface. e Repeated treatment core 224 with F.C.S.B.sr after FW
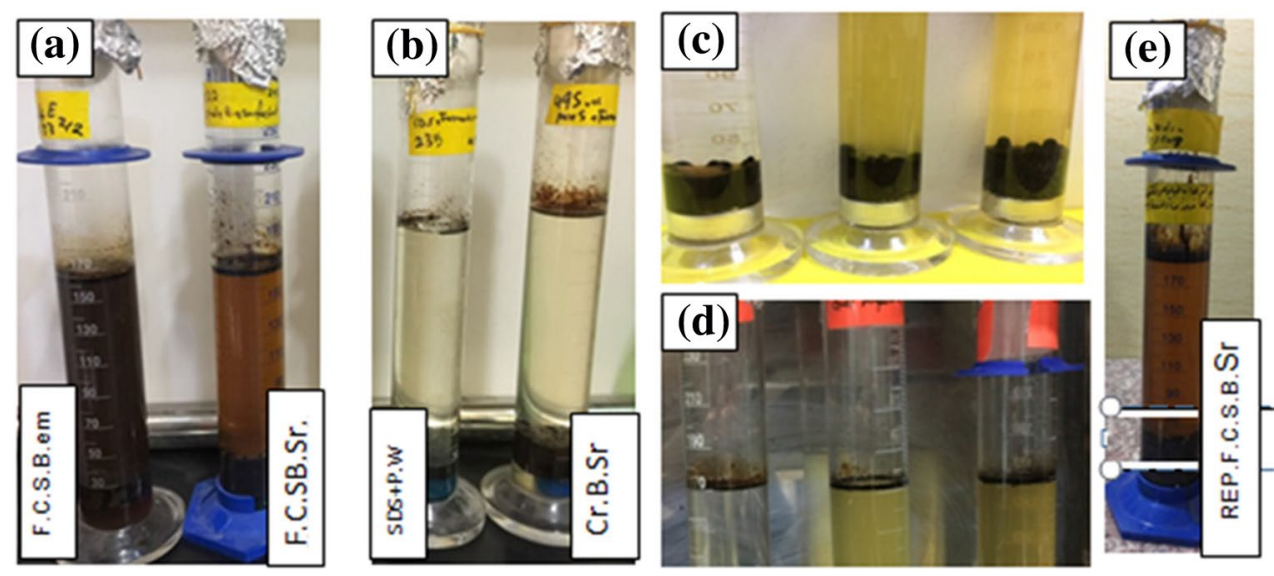

Table 8 Effect of biosurfactant and bioemulsifier on oil recovery

\begin{tabular}{|c|c|c|c|c|c|c|c|c|c|}
\hline Run no. & Sample no. & Recovery liquid & $\begin{array}{l}\text { Surface ten- } \\
\text { sion } \mathrm{mN} / \mathrm{m}\end{array}$ & $\begin{array}{l}\text { Perme- } \\
\text { ability, } \\
\mathrm{mD}\end{array}$ & $\begin{array}{l}\text { Core plug } \\
\text { vol, cc }\end{array}$ & Pore vol, cc & Dry weight, g & $\begin{array}{l}\text { Saturated with } \\
\text { oil weight, g }\end{array}$ & Recovery $\%$ \\
\hline 1 & 224 & P.W & 48.18 & 770 & 34 & 6.32 & 76.70 & 82.01 & 12.10 \\
\hline 2 & 222 & F.C.S.B.Sr & 27.61 & 843 & 18 & 4.46 & 58.23 & 61.44 & 66.90 \\
\hline 3 & 233 & F.C.S.B.em & 28.94 & 197 & 25 & 4.00 & 61.47 & 64.86 & 34.00 \\
\hline 4 & 230 & Cr.B.sr+F.W & 28.04 & 228 & 24 & 4.49 & 55.28 & 58.87 & 15.60 \\
\hline 5 & 235 & $\mathrm{SDS}+\mathrm{FW}$ & 36.44 & 210 & 20 & 3.60 & 47.13 & 49.93 & 13.60 \\
\hline 6 & 224 Rep & F.C.S.B.Sr & 27.61 & 770 & 34 & 6.32 & & & 3.80 \\
\hline 7 & 227 & P.W & 48.18 & 580 & 20 & 4.19 & 45.34 & 48.91 & 14.60 \\
\hline 8 & 225 & F.C.S.B.Sr & 27.61 & 516 & 22 & 4.90 & 54.18 & 58.37 & 39.70 \\
\hline 9 & 221 & F.C.S.B.em & 28.94 & 1914 & 26 & 6.22 & 55.58 & 60.89 & 44.70 \\
\hline 10 & 227 Rep & Cr. B. Sr & 27.61 & 580 & 20 & 4.19 & & & 7.90 \\
\hline
\end{tabular}


Fig. 10 a Oil recovery with different liquids. b Oil recovery by the F.C.S.B.Sr. after treated with producing water
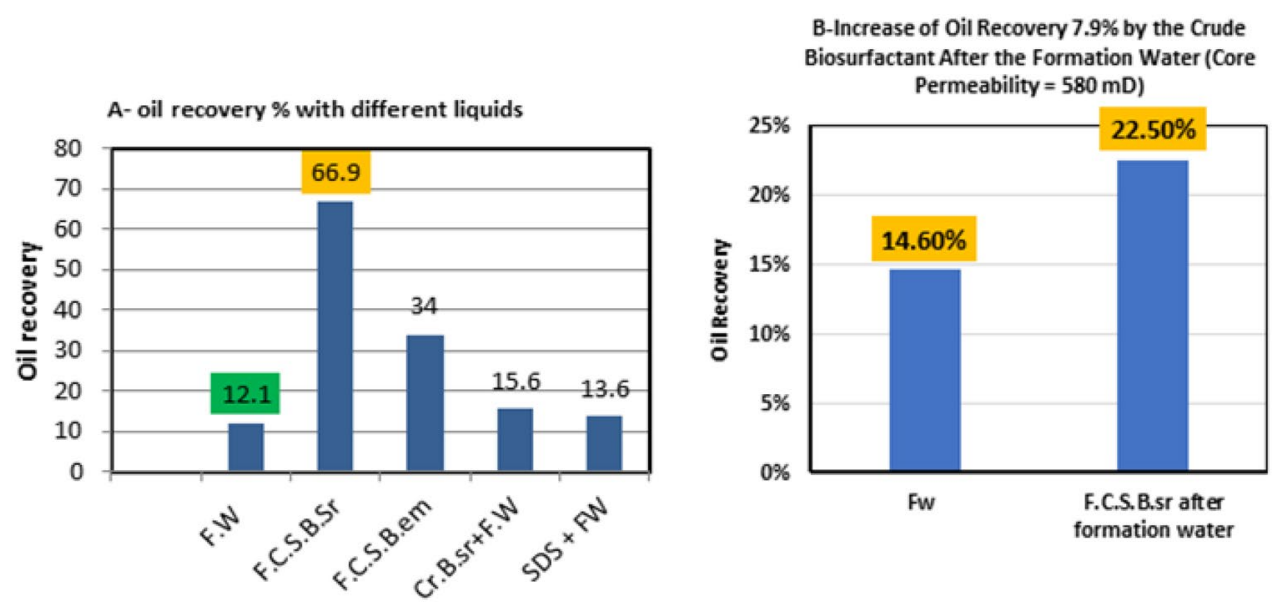

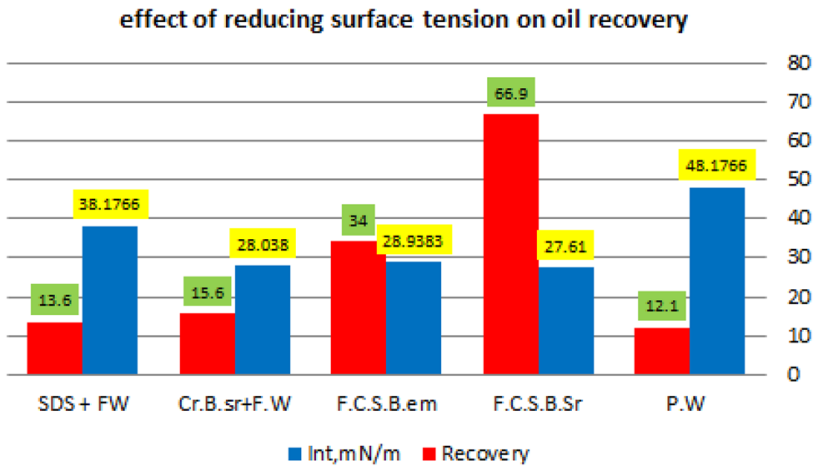

Fig. 11 Effect of surface tension on oil recovery

polar water molecules are repulsed from the hydrophobic surface (Sari et al. 2014).

\section{Oil displacement}

The cell-free supernatant of the two selected isolates caused oil spreading as a clear zone on surface oil layer indicating the presence of biosurfactant. A larger diameter of clear zone represents the higher activity of the testing solution (Rodrigues et al. 2006). Enterobacter aerogenes $B 19$ strain showed a zone of displacement diameter $7.6 \mathrm{~cm}$ while displacement had observed by Bacillus cereus ISU02 strain $8.4 \mathrm{~cm}$ as shown in Fig. 7.

\section{Emulsification index test E24}

Enterobacter aerogenes B19 strain showed the most emulsification activity in all oils tested more than Bacillus cereus ISU-02 strain (Fig. 8 and Table 7) indicating that fraying and crude oil were the most emulsifying. Aniyanwu et al. (2011) revealed that the capacity of a biosurfactant to emulsify hydrocarbon-water blend has been observed to improve the biodegradation of the hydrocarbons and is possibly helpful in improved oil recovery.

\section{Effect of biosurfactant and bioemulsifier on oil recovery}

Figure 9 shows experiments of oil recovery by imbibition process. Table 8 shows results of oil recovery using the imbibition experiments. It can be observed that F.C.S.B.sr gave the highest oil recovery of $66.9 \%$ with core permeability of $843 \mathrm{mD}$, followed by F.C.S.B.em with oil recovery of $34 \%$ for core permeability $197 \mathrm{mD}$, while the lowest rate of oil recovery was $12.1 \%$ for FW with permeability of 770 $\mathrm{mD}$. Rate of oil recovery by FW + SDS was $13.6 \%$ for core permeability of $210 \mathrm{mD}$. Results of the present study are in the range of results obtained by other researchers in previous studies (Bordoloi et al. (2008) and Suthar et al. (2008)).

The most important factors affecting oil recovery in the present experiments are the interfacial tensions and core permeability. Reduction in the interfacial tension and increase in the permeability result in increase in oil recovery. Figure 10a-b show effect of permeability, and Fig. 10 shows effect of the interfacial tension (Fig. 11).

Although permeability of the core that was treated with F.C.S.B.em is less than core treated with the commercial surfactant SDS, F.C.S.B.em was more efficient than SDS for oil recovery. The results also showed that additional oil recovery rates have been obtained from the core plugs that were treated with the FW and retreated with the biosurfactants (Runs 6 and 10 in Table 8) which indicates that the biosurfactants in the second imbibition process have increased oil recovery. Increment in oil recovery was a result of reducing the interfacial tension. Observation matches

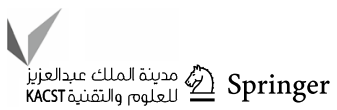


with conclusions of previous studies (Gudiña et al. 2012; Al-Sulaimani et al. 2012; Zhao et al. 2017).

The experiment was conducted for all liquids in fixed conditions such as temperature, time and quantity regardless of other conditions that could hinder the imbibition process. For example, formation of asphaltene aggregates might be responsible for limiting the liquid flow and leading to impede the flow through the channel as mentioned by Mozaffari et al. (2017).

Open Access This article is licensed under a Creative Commons Attribution 4.0 International License, which permits use, sharing, adaptation, distribution and reproduction in any medium or format, as long as you give appropriate credit to the original author(s) and the source, provide a link to the Creative Commons licence, and indicate if changes were made. The images or other third party material in this article are included in the article's Creative Commons licence, unless indicated otherwise in a credit line to the material. If material is not included in the article's Creative Commons licence and your intended use is not permitted by statutory regulation or exceeds the permitted use, you will need to obtain permission directly from the copyright holder. To view a copy of this licence, visit http://creativecommons.org/licenses/by/4.0/.

\section{References}

Abouseoud M, Maachi R, Amrane A, Boudergua S, Nabi A (2008) Evaluation of different carbon and nitrogen sources in production of biosurfactant by Pseudomonas fluorescens. Desalination 223(1-3):143-151

Al-Bahry SN, Al-Wahaibi YM, Elshafie AE, Al-Bemani AS, Joshi SJ, Al-Makhmari HS, Al-Sulaimani HS (2013) Biosurfactant production by Bacillus subtilis B20 using date molasses and its possible application in enhanced oil recovery. Int Biodeterior Biodegrad 81:141-146

Almansoory AF, Idris M, Abdullah SRS, Anuar N (2014) Screening for potential biosurfactant producing bacteria from hydrocarbon-degrading isolates. Adv Environ Biol 8(3):639-647

Al-Sulaimani H, Al-Wahaibi Y, Al-Bahry S, Elshafie A, Al-Bemani A, Joshi S (2012) Residual-oil recovery through injection of biosurfactant, chemical surfactant, and mixtures of both under reservoir temperatures: induced-wettability and interfacial-tension effects. SPE Reservoir Eval Eng 15(02):210-217

Anyanwu CU, Obi SKC, Okolo BM (2011) Lipopeptide biosurfactant produced by Serratia merscens NSK-1 strain isolated from petroleum contaminated soil. J Appl Sci Res 7(1):79-87

Austad T, Matre B, Milter J, Saevareid A, Øyno L (1998) Chemical floodingof oil reservoirs 8. Spontaneous oil expulsion from oil-and water-wet low permeablechalk material by imbibition of aqueous surfactant solutions. Colloids Surf A 137(1-3):117-129

Barakat KM, Hassan SW, Darwesh OM (2017) Biosurfactant production by haloalkaliphilic Bacillus strains isolated from Red Sea, Egypt. Egypt J Aquat Res 43(3):205-211. https://doi. org/10.1016/j.ejar.2017.09.001

Bento FM, De Oliveira Camargo FA, Okeke BC, Frankenberger WT (2005) Diversity of biosurfactant producing microorganisms isolated from soils contaminated with diesel oil. Microbiol Res 160:249-255

Bicca FC, Fleck LC, Ayub MAZ (1999) Production of biosurfactant byhydrocarbon degrading Rhodococcusruber and Rhodococcuserythropolis. Revista deMicrobiologia 30(3):231-236
Bordoloi NK, Konwar BK (2008) Microbial surfactant-enhanced mineral oil recovery under laboratory conditions. Colloid Surf B 63:73-82

Carrillo PG, Mardaraz C, Pitta-Alvarez SI, Giulietti AM (1996) Isolationand selection of biosurfactant-producing bacteria. World $\mathrm{J}$ Microbiol Biotechnol 12(1):82-84

Cooper DG, Goldenberg BG (1987) Surface-active agents from two Bacillus species. Appl Environ Microbiol 53:224-229

Cooper DG, Macdonald CR, Duff SJB, Kosaric N (1981) Enhanced production of surfactin from Bacillus subtilis by continuous product removal and metal cation additions. Appl Environ Microbiol 42:408-412

Dukhande M, Warde M (2016) Isolation and characterization of potent biosurfactant producing bacteria from petroleum contaminated soil and sea water. Int J Eng Res Technol 5(3)

Farzaneh NA (2011) Evaluating the potential of low-salinity waterlooding to enhance the oil recovery in limestone reservoir, master'sthesis, Stavanger University

George S, Jayachandran K (2008) Analysis of rhamnolipid biosurfactants produced through submerged fermentation using orange fruit peelings as sole carbon source. Appl Biochem Biotechnol 158:694-705. https://doi.org/10.1007/s12010-008-8337-6

Gittel A, Sørensen KB, Skovhus TL, Ingvorsen K, Schramm A (2009) Prokaryotic community structure and sulfate reducer activity in water from high-temperatureoil reservoirs with and without nitrate treatment. Appl Environ Microbiol 75(22):7086-7096

Golabi E, Seyedin AF, Ayat ES (2009) Chemical induced wettabilityalteration of carbonate reservoir rocks

Gudiña EJ, Rodrigues LR, Teixeira JA, Pereira JF, Coutinho JA, Soares LP (2012) Biosurfactant producing microorganisms and its application to enhance oil recovery at lab scale. In: SPE EOR conference at oil and gas West Asia. Muscat: Society of Petroleum Engineers

Kuiper I, Lagendijk EL, Pickford R, Derrick JP, Lamers GEM, Thomas-Oates JE et al (2003) Characterization of two Pseudomonas putida lipopeptide biosurfactants, putisolvin I and II, which inhibit biofilm formation and break down existing biofilms. Mol Microbiol 51:97-113

Meenal D, Madhura W (2016) Isolation and characterization of potent biosurfactant producing bacteria from petroleum contaminated soil and sea water. Int J Eng Res Technol. 5(03). ISSN:2278-0181

Morikawa M, Hirata Y, Imanaka T (2000) A study on the structurefunction relationship of lipopeptide biosurfactants. BBA Mol Cell Biol Lipids 1488(3):211-218

Mozaffari S, Tchoukov P, Mozaffari A, Atias J, Czarnecki J, Nazemifard N (2017) Capillary driven flow in nanochannels: application to heavy oil rheology studies. Colloids Surf A 513:178-187

Nikzad Amoli F (2011) Evaluating the potential of low-salinity water flooding to enhance the oil recovery in limestone reservoir. Master's thesis, University of Stavanger, Norway

Nnaemeka O, Franklin N, Stanley O (2018) A Review of Microbial Enhanced Oil Recovery Applications Projects. Oil Gas Res 4(152):2472-0518

Pal S, Mushtaq M, Banat F, Al Sumaiti AM (2018) Review of surfactantassistedchemical enhanced oil recovery for carbonate reservoirs: challenges and futureperspectives. Pet Sci 15(1):77-102

Płaza GA, Zjawiony I, Banat IM (2006) Use of different methods fordetection of thermophilic biosurfactant-producing bacteria from hydrocarboncontaminatedand bioremediated soils. J Pet Sci Eng 50(1):71-77

Qazi MA, Subhan M, Fatima N, Ali MI, Ahmed S (2013) Role ofbiosurfactant produced by Fusarium sp. BS-8 in enhanced oil recovery (EOR) throughsand pack column. Int J Biosci Biochem Bioinform 3(6):598 
Rashid S, Charles TC, Glick BR (2012) Isolation and characterization of new plant growth-promoting bacterial endophytes. Appl Soil Ecol 61:217-224

Rodrigues LR, Teixeira JA, van der Mei HC, Oliveira R (2006) Physicochemical and functional characterization of a biosurfactant produced by Lactococcus lactis 53. Colloids Surf B: Biointerfaces 49(1):79-86. https://doi.org/10.1016/j.colsurfb.2006.03.003

Rosli Wan Sulaiman W, Soo Lee E (2012) Simulation of surfactant basedenhanced oil recovery. Open Pet Eng J 5(1)

Sabnis S, Juvale V (2016) Enrichment and isolation of biosurfactant producers from marine environment. Int J Curr Microbiol Appl Sci 5(4):730-740

Sari M, Kusharyoto W, Made Artika I (2014) Screening for biosurfactant-producing yeast: confirmation of biosurfactant production. Biotechnology 13:106-111

Sheng JJ (2010) Modern chemical enhanced oil recovery: theory and practice. Gulf Professional Publishing

Siegmund I, Wagner F (1991) New method for detecting rhamnolipids excreted by Pseudomonas species during growth on mineral agar. Biotechnol Tech 5:265-268

Standnes DC, Austad T (2003) Wettability alteration in carbonates: interaction between cationic surfactant and carboxylates as a key factor in wettability alteration from oil-wet to water-wet conditions. Colloids Surf A: Physicochem Eng Asp 216:243-259

Strand S, Standnes DC, Austad T (2003) Spontaneous imbibition of aqueous surfactant solutions into neutral to oil-wet carbonate cores: Effects of brine salinity and composition. Energy fuels 17(5):1133-1144

Suthar H, Hingurao K, Desai A, Nerurkar A (2008) Evaluation of bioemulsifier mediated microbial enhanced oil recovery using sand pack column. J Microbiol Methods 75:225-230

Syldatk C, Lang S, Wagner F, Wray V, Witte L (1985) Chemical and physical characterization of four interfacial-active rhamnolipids from Pseudomonas spec. DSM 2874 grown on n-alkanes. Zeitschrift Naturforschung C 40:51-60
Tabatabaee A, Mazaheri Assadi M, Noohi A, Sajadian V (2005) Isolation of biosurfactant producing bacteria from oil reservoirs. Iran J Environ Health Sci Eng 2(1):6-12

Thavasi R, Sharma S, Jayalakshmi S (2011) Evaluation of screening methods for the isolation of biosurfactant producing marine bacteria. J Pet Environ Biotechnol S1:1-6

Tugrul T, Cansunar E (2005) Detecting surfactant-producing microorganisms by the drop-collapse test. World J Microbiol Biotechnol $21: 851-853$

Volkering F, Breure AM, Rulkens WH (1998) Microbiological aspects of surfactant use for biological soil remediation. Biodegradation $8: 401-417$

Walter V, Syldatk C, Hausmann R (2010) Screening concepts for the isolation of biosurfactant producing microorganisms. In: Ramkrishna S (ed) Biosurfactants, vol 672. Springer, New York, pp 1-13 ISBN: 9781441959799

Xiao M, Sun SS, Zhang ZZ, Wang JM, Qiu LW, Sun HY, Song ZZ, Zhang BY, Gao DL, Zhang GQ, Wu WM (2016) Analysis of bacterial diversity in two oil blocks from two low permeability reservoirs with high salinities. Sci Rep 6:19600. https://doi. org/10.1038/srep19600

Zafra G, Absalón ÁE, Cuevas MDC, Cortés-Espinosa DV (2014) Isolation and selection of a highly tolerant microbial consortium with potential for PAH biodegradation from heavy crude oil-contaminated soils. Water Air Soil Pollut 225:1826

Zhao F, Shi R, Cui Q, Han S, Dong H, Zhang Y (2017) Biosurfactant production under diverse conditions by two kinds of biosurfactantproducing bacteria for microbial enhanced oil recovery. J Pet Sci Eng 157:124-130

Publisher's Note Springer Nature remains neutral with regard to jurisdictional claims in published maps and institutional affiliations. 